\title{
The Impact of Alum on the Bulking of a Full Scale Activated Sludge Plant
}

Peter Ojo and Augustine O. Ifelebuegu

\begin{abstract}
The activated sludge plant (ASP) is one of the main wastewater treatment processes in the UK. With the increasing stringent requirement for effluent quality, there has been a considerable increase in the use of chemicals for phosphorus precipitation in ASPs to achieve effluent consents. Alum is one of the most widely used chemicals in the treatment of wastewater. In this study, we examine the impact of varying concentrations of alum on the bulking and settleability of a full-scale activated sludge plant with simultaneous co-precipitation. The results showed an improvement in the settleability of the activated sludge with the initial stirred sludge volume index (SSVI) before alum dosing dropping from 105 to 85 after one sludge age. The SSVI increased to 155 with the settleability and floc compactability deteriorating at a dose rate of $145 \mathrm{mg} / \mathrm{L}$ of alum. The bulking of the sludge was caused by a combination of the filaments present and the surface chemistry of the activated sludge flocs.
\end{abstract}

Keywords- Activated Sludge, Bulking, FST, Settleability

\section{Introduction}

The activated sludge treatment is one of the most widely used processes for biological treatment of wastewater (Thompson et al., 2001; Hammer, 2008). The treatment process comprises of two (2) unit operations namely; aeration and secondary clarification. The aeration process occurs within an aeration tank where organic carbon, ammonium and phosphate are removed from the wastewater using microbial population like algae, protozoans, bacteria and metazoan (Richard, 1989; Jeniken, 2003; Bitton, 2005;). The secondary treatment takes place within the final sedimentation tank (FST) where both clarification and thickening of activated sludge is performed for an effective final effluent quality (Metcalf and Eddy 2004).

The separation of the mixed liquor suspended solids (MLSS) from treated wastewater in the FST is one of the fundamental challenges of the ASP process. Poor MLSS separation often occurs due to bulking of the activated sludge. Bulking is a phenomenon that takes place in an activated sludge plant when the sludge occupies an excessive volume that does not settle readily and in extreme cases results in effluent that contains an an excessive amount of suspended solids (Tomlinson, 1976). Gerardi (2002) also defined bulking sludge as the excessive growth of filamentous bacteria. Moreover, research has reported that the estimated volume fraction of filamentous bacteria that could result in bulking sludge ranges between 1 20\% (Palm et al., 1984; Kappeler and Gujer, 1994). However, Wanner (1994) reported that the filamentous bacteria is not just vital to the floc formation process but its filaments act as a backbone for the flocs development and as an attachment for fingered zoogloeal ramigera organism. This filamentous bacteria and zoogleal organism are both vital in achieving a satisfactory sludge quality and efficient clarification in the FST.

As a result of the increasingly strigent requirements for effluent quality; there has been increased used of chemicals for nutrient removal in the UK. Ferric and alum salts are the predominantly used salts for phosphorus removal in the UK. While there is a significant body of work on the impact of various parametres on sludge settleability ( Jobbagy et al., 2002; Jenkins et al., 2003; Jin etal., 2003), there is limited research on the effects of chemical dosing. This Paper examines the impact of alum dosing on bulking properties of a full scale activated sludge plant.

\section{Methods and Design Approach}

The work was carried out on full scale wastewater treatment plant located in the West Midlands, UK. The site flow data and operating parameters are reported in Table 1. Aluminium sulphate was dosed at varying dose rates $(20 \mathrm{mg} / \mathrm{L}$ to 185 $\mathrm{mg} / \mathrm{L}$ ) during a plant trial for several months. The bulking properties were determined as a function of the stirred sludge volume index (SSVI) and zone settling velocity (ZSV). The settleability of the activated sludge at various dose rates was also modelled using the Pitman and White settling curves as has been previously described in Ojo and Ifelebuegu, 2015.

Table 1. Site Flow Data for Sewage Treatment Works

\begin{tabular}{|c|c|}
\hline Parameters & Data \\
\hline FFT $\left(\mathrm{m}^{3} /\right.$ day $)$ & $6462 \mathrm{~m}^{3} /$ day \\
\hline DWF $\left(\mathrm{m}^{3} /\right.$ day $)$ & $2743 \mathrm{~m}^{3} /$ day \\
\hline RAS $=0.5 *$ DWF $\left(\mathrm{m}^{3} /\right.$ day $)$ & $1371.5 \mathrm{~m}^{3} /$ day \\
\hline Normal flow $=1.2 * \mathrm{DWF}\left(\mathrm{m}^{3} /\right.$ day $)$ & $3291.6 \mathrm{~m}^{3} /$ day \\
\hline Max. RAS $=1.5 * \mathrm{DWF}$ & $4114.5 \mathrm{~m}^{3} /$ day \\
\hline Influent MLSS $(\mathrm{mg} / \mathrm{l})$ & $3000 \mathrm{mg} / \mathrm{l}$ \\
\hline Tank Diameter & $24 \mathrm{~m}$ \\
\hline Side wall Depth & $5 \mathrm{~m}$ \\
\hline
\end{tabular}

Peter Ojo and Augustine O. Ifelebuegu

School of Energy, Construction and Environment, Faculty of Engineering, Environment \& Computing, Coventry University, Coventry, CV1 5FB, United Kingdom. 


\section{A. Sludge Settleability Index}

\section{SVI (sludge volume Index) and ZSV (zone settling velocity) Expression}

According to (Metcalf and Eddy 2004), the SVI has been defined as the volume of $1 \mathrm{~g}$ of sludge after 30 mins of settling. The approach of measurement reported was placing a mixed liquor sample in either a $2 \mathrm{~L}$ measuring cylinder and settled volume was measured after $30 \mathrm{~min}$ and equivalent sample MLSS concentration. The numerical value was computed using the following expression (Eqn 1.0):

$$
\text { SSVI }(\mathbf{m l} / \mathbf{g})=\frac{\text { Volume of Settled Sludge after } 30 \mathrm{mins}, \mathrm{ml} / \mathrm{f}(100 \mathrm{mg} / \mathrm{g})}{\text { MLSS Concentration } \frac{\mathrm{mg}}{l}}
$$

Eqn 1.0

\section{ZSV (Zone Settling Velocity) Expression}

Although, various studies have been conducted to examine the relationship between zone settling velocity and activated sludge concentration, the most acceptable models are those suggested by Vesilind (1968) and Dick (1972). These models define the connection between zone settling velocity and sludge concentration which is considered as follows:

\section{Vesilind Equation}

$\mathrm{ZSV}=\mathrm{v}_{0} * \exp \left(-\mathrm{k} . X_{a}\right)$

Dick's Equation

$\mathrm{ZSV}=\mathrm{V}_{0} *\left(X_{t}\right)^{K}$

Where,

$\mathrm{ZSV}=$ zone settling velocity

$\mathrm{X}=$ activated sludge concentration

$V_{0}, \mathrm{k}, v_{0}$ and $\mathrm{k}=$ sludge settleability constants

Also, following the research conducted by Pitman (1984)

involving analysis of six years full scale study which resulted

in the development of an empirical relationship between the constants of vesilind's equation and SSVI. The correlation obtained was as follows:

$\frac{\mathrm{V}_{0}}{\mathrm{~K}}=68 * \exp \left(-0016 *\right.$ SSVI $\left._{\mathbf{3 . 5}}\right)$

Eqn 1.3

The data of Ekama and Marias (1986) was analysed along with that of other researchers (White 1975; Koopman and Cadee 1983) and came up with the findings that pitman's empirical expression in Eqn 1.3 resulted in a good description for all and that a relationship exists between $\frac{V_{0}}{\mathrm{~K}}$ and $\mathrm{k}$. This is expressed as follows:

$\mathrm{K}=0.88-0.393 * \log \left(\mathrm{V}_{0} * \mathrm{k}\right)$

Eqn 1.4

However, since the value of $k$ is known then the value of $v_{0}$ can be computed as follows using Eqns (1.3 and 1.4):

$\mathrm{v}_{0}=(\underline{\mathrm{K}}) * \mathrm{k}$

Eqn 1.5

According to suggestions from Catunda et al. (1989), rearranging Eqn 1.4 to 1.5 will make it possible to express k and $V_{0}$ as a function of $\mathrm{SSVI}_{3.5}$ which can be expressed as follows:

$\mathbf{k}=\mathbf{0 . 1 6}+2.7 * 10^{-3} * \mathrm{SSVI}_{3.5}$

Eqn 1.6
Upon substituting Eqns (1.5 and 1.6) into Eqn (1.4) the following expression would be realised:

$$
v_{0=}\left(10.9+0.18 * \mathrm{SSVI}_{3.5}\right) * \exp \left(-0.016 * \mathrm{SSVI}_{3.5}\right) \quad \text { Eqn } 1.7
$$

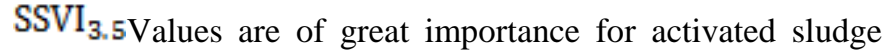
process and hence Eqn 1.7 can be expressed as follows:

$$
\mathrm{v}_{0}=\left(11.2-\mathbf{0 . 0 6} * \mathrm{SSVI}_{3.5}\right)
$$

Eqn 1.8

\section{Results and Discussion}

\section{Impact of Dosing on Bulking}

The results of the impact of alum dosing $(20,40,60,80,100$, $125,145,165$ and 185$) \mathrm{mg} / \mathrm{l}$ on activated sludge settleability index (ZSV and SSVI) are presented in Figures 1 and 2. It was noticed that the ZSV values $(1.9,2.0,2.3$ and $2.5 \mathrm{~m} / \mathrm{h})$ increased initially with increasing concentration of alum doses $(20,40,60$ and $80 \mathrm{mg} / \mathrm{l})$ and started to decrease $(2.3,1.4,0.6$, 0.5 , and $0.4 \mathrm{~m} / \mathrm{h}$ ) after $100 \mathrm{mg} / \mathrm{L}$ dose concentration $(100,125$, 145,165 and $185 \mathrm{mg} / \mathrm{l}$ ). A similar trend is observed with the SSVI, which started increasing at a dose rate of $100 \mathrm{mg} / \mathrm{L}$.

The improvement of the sludge settleability (lower SSVI values) at initial dose rates (20 to $100 \mathrm{mg} / \mathrm{L}$ ) is linked to the surface chemistry of the sludge and the decreased number of filaments usually within the first sludge age (Eikelboom et al., 1998, Agridiotis et al., 2007). The action of alum on enhancing the settleability can also be further explained by charge neutralization of negatively charged sludge flocs by the positively charged aluminium hydroxides that are absorbed onto the floc particles (Urbain et al., 1992; Agridiotis et al., 2007). This agrees with the work of Mikkelsen, 1996 and Thompson and Foster, 2003 who demonstrated that low SVI values are associated with low surface charges.

Furthermore, the increasing dose of alum which increases the activated sludge $\mathrm{pH}$ contributed to improving settling during the initial dose rates. Previous work by Ghanizadeh and Sarrafpour (2001) showed that increasing $\mathrm{pH}$ in the aeration basin of an ASP reduces SVI values and improves settleability due to improved biofloculation. 


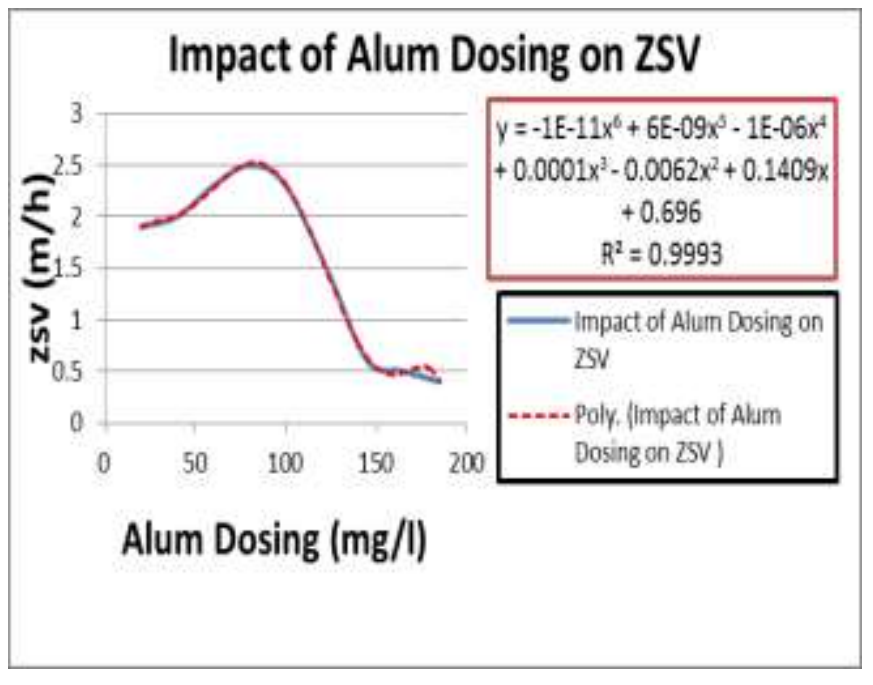

Figure 1. Effects of varying concentrations of alum (mg/L) on $\mathrm{ZSV}(\mathbf{m} / \mathbf{h})$

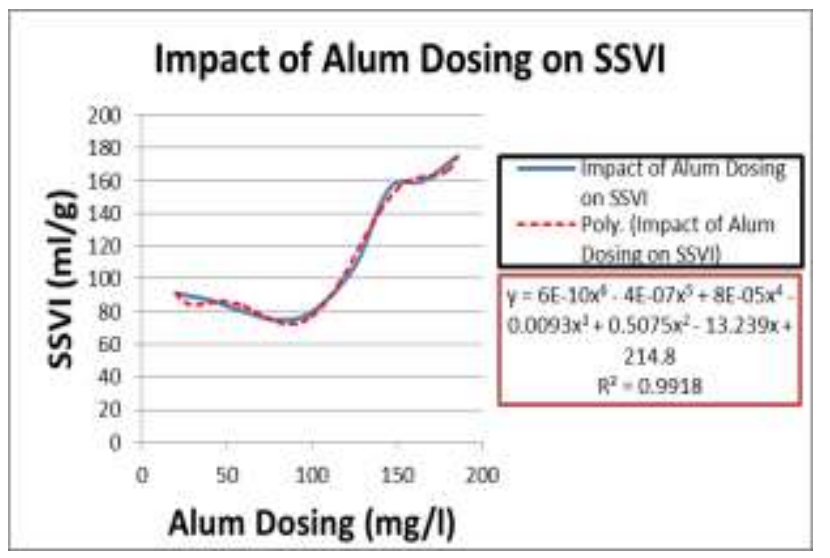

Figure 2. Effect of varying concentrations of alum $(\mathrm{mg} / \mathrm{L})$ on SSVI ( $\mathrm{ml} / \mathrm{g})$

At a dose concentration of $145 \mathrm{mg} / \mathrm{L}$ of alum, the SSVI exceeded the 120 mark which is considered the maximum concentration at which bulking sets in (Agridiotis et al., 2007). The increase in SSVI with increasing alum dosing at $145 \mathrm{mg} / \mathrm{L}$ and beyond may be due to the formation of an open, large precipitate that has a slow settling rate which hinders compressibility of the activated sludge biomass and concentrated underflow, resulting to bulking sludge. As surface charges play a significant role in sludge settleability; the bulking experience at the higher dose rate could also be attributed to the possibility of charge reversal (Agridiotis et al., 2007).

\section{Modelling the Settleability of Alum Dosed Sludge in the FST (at 20, 145 and $185 \mathrm{mg} / \mathrm{L}$ )}

\section{Evaluation of Pitman and White Settling Curves for Alum Dosed Sludge at 20mg/l}

Fig 1 reveals an adequate settling within the clarifier with an alum dosing concentration of $20 \mathrm{mg} / \mathrm{l}$. Permissible flux and actual flux value were $1.54 \mathrm{~kg} / \mathrm{m}^{2} / \mathrm{hr}$ and $3.18 \mathrm{~kg} / \mathrm{m}^{2} / \mathrm{hr}$ with an SSVI of $91 \mathrm{ml} / \mathrm{g}$. The ratio of actual flux to the permissible was $48.37 \%$. The clarifier has its underflow line completely under the pitman and white settling curve which shows that the clarifier did not fail in clarification because the solid entering the clarifier has enough settling time to settle in the clarifier before going over the effluent weir. The clarifier had its underflow rate line (UFR) below the descending limb of the settling flux curve and this shows that the clarifier is performing its thickening function. This is an indication that the sludge was adequately compacting and settling and was significantly enhanced by the $20 \mathrm{mg} / \mathrm{L}$ alum dose.

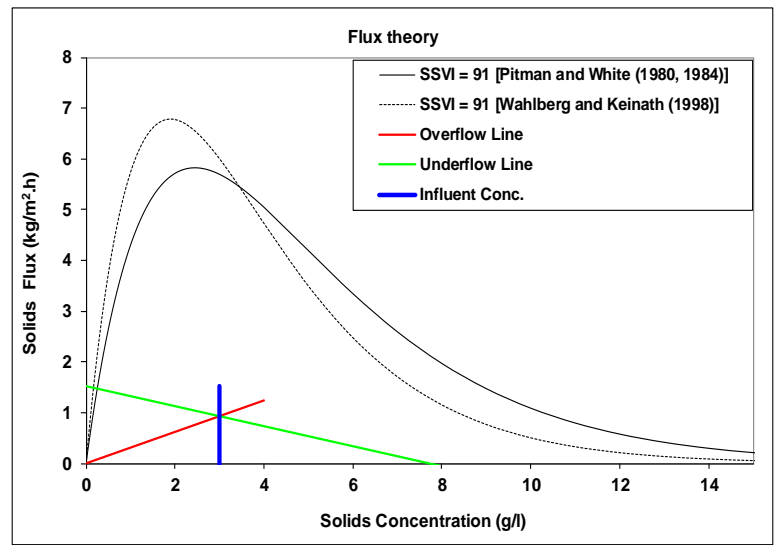

Fig 1. Settling Curve for alum dosed sludge at $20 \mathrm{mg} / \mathrm{l}$

\section{Evaluation of Pitman and White Settling Curves for Alum Dosed Sludge at $145 \mathrm{mg} / \mathrm{l}$}

It was observed that settling within the clarifier was adversely affected at dose rates of $145 \mathrm{mg} / \mathrm{L}$ and beyond (Figure 2). The actual flux value for the various concentrations ( 145,165 and $185 \mathrm{mg} / \mathrm{l})$ was constant at $1.54 \mathrm{~kg} / \mathrm{m}^{2} / \mathrm{hr}$ but at an alum dosing concentration of $145 \mathrm{mg} / \mathrm{l}$ with an SSVI of $155 \mathrm{ml} / \mathrm{g}$ the permissible flux value was $2.11 \mathrm{~kg} / \mathrm{m}^{2} / \mathrm{hr}$. While at an increased alum dosing of $165 \mathrm{mg} / \mathrm{l}$ with an SSVI of $160 \mathrm{ml} / \mathrm{g}$ the permissible flux value was $2.06 \mathrm{~kg} / \mathrm{m}^{2} / \mathrm{hr}$ and at alum dosed concentration of $185 \mathrm{mg} / \mathrm{l}$ and SSVI of $175 \mathrm{ml} / \mathrm{g}$ the permissible flux value was $1.92 \mathrm{~kg} / \mathrm{m}^{2} / \mathrm{hr}$. The ratio of the actual to permissible flux for various concentration $(145,165$ and $185 \mathrm{mg} / \mathrm{l}$ ) was $72.90 \%, 74.70 \%$ and $80.04 \%$ respectively. 


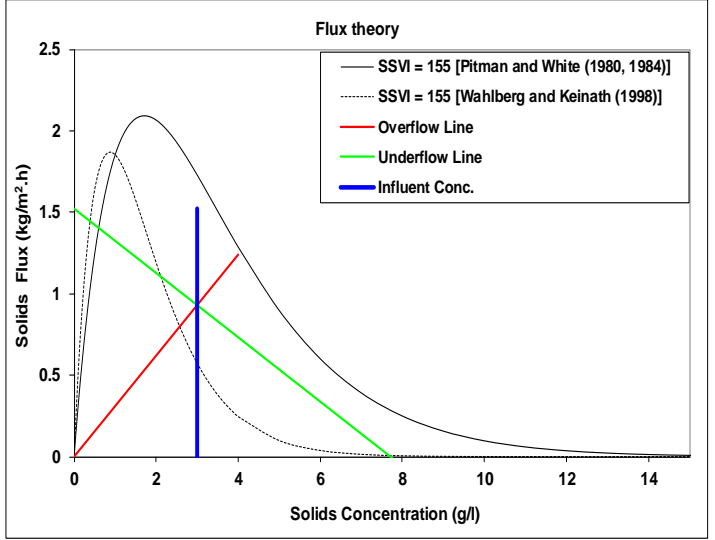

Fig 2 Settling Curve for alum dosed sludge at $145 \mathrm{mg} / \mathrm{l}$

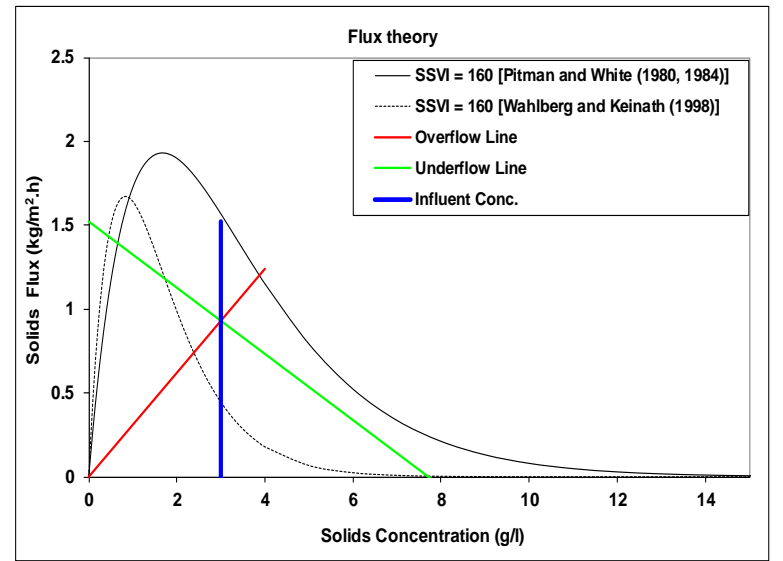

Fig 3 Settling Curve for alum dosed sludge at $165 \mathrm{mg} / \mathrm{l}$

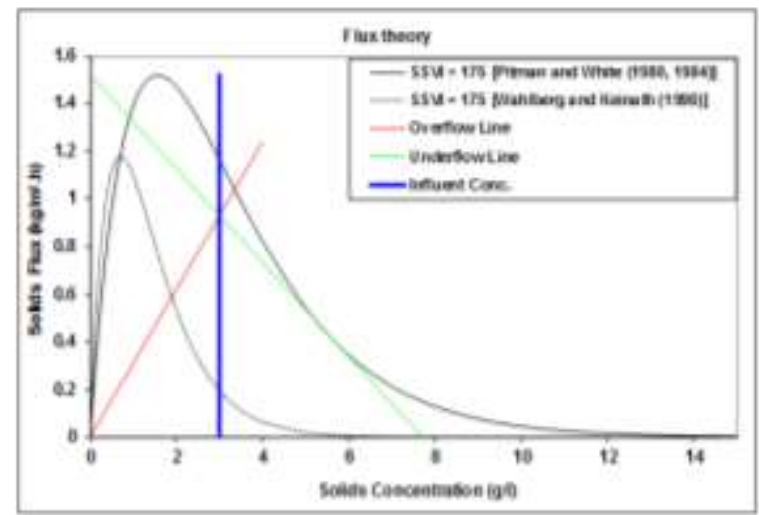

Fig 4 Settling Curve for alum dosed sludge at $185 \mathrm{mg} / \mathrm{l}$

However, evaluating Fig 2, Fig 3 and Fig 4, it can be deduced that the state point (SP) was outside the pitman and white operational settling curve and the underflow line (UFR) intersects the descending limb of the curve. This showed that the clarifier was failing in thickening and clarification with sludge blanket levels rising within the clarifier and hence bulking activated sludge. This supports the initial finding that at higher alum dosing (145 mg/L and beyond) bulking sets in due mainly to changes in surface chemistry and possible charge reversal.

\section{Conclusion}

The impact of alum dosing on a full scale treatment plant in the UK was investigated. Alum dosing was found to enahnce sludge settleability through charge neutralisation and the reduction of filaments at lower dose rates. At a higher dose rate of $145 \mathrm{mg} / \mathrm{L}$ there was bulking of the ASP as a result of the formation of an open, large precipitate that had a slow settling rate which hindered compressibility of the activated sludge biomass and concentrated underflow.

\section{References}

[1] Agridiotis, V., Forster, C.F. and Carliell-Marquet, C., (2007) 'Addition of $\mathrm{Al}$ and $\mathrm{Fe}$ salts during treatment of paper mill effluents to improve activated sludge settlement characteristics'. Bioresource Technology, 98(15), pp.29262934.

[2] Bitton, G, Wastewater Microbiology (3rd edn.), 2005, Wiley-Liss, USA, p.765

[3] Burt, D. J., and Ganeshalingam, J. (2005) Design and optimisation of final clarifier performance with CFD modelling: the Ciwem / Aqua Environ Joint Conference on Design and Operation of Activated Sludge Plants [online] available from <http://74.125.155.132/scholar?q=cache:8e3dfp6bukij:sch olar.google.com/\&hl=en\&as_sdt=0, $5>$ [20 May 2016]

[4] Catunda P.F.C., Van Haandel A.C., Araujo L.S and Vilar A. (1989) 'Determination of the settleability of activated sludge: Presented At the $15^{\text {th }}$ Congress of the Brazillian Sanitary Engineering Organisation'; Belem

[5] Daigger, G.T. (1995) 'Development of refined clarifier operating diagrams using an updated settling characteristics database'. Journal of water environment research 67, (1) pp.95-100.

[6] Dick, R.I., and Vesilind, P.A. (1969) 'The Sludge Volume Index-What Is It?' Journal WPCF 41, p.7

[7] Ekama, G.A., and Marais, G.V.R. (1986) 'sludge settlability and secondary settling and design procedures'. Journal of Water Pollution Control 87, 101-113. 
Proc. of the International Conference on Advances in Bio-Informatics and Environmental Engineering - ICABEE 2016. Copyright (C) Institute of Research Engineers and Doctors. All rights reserved.

ISBN: 978-1-63248-100-9 doi: 10.15224/ 978-1-63248-100-9-57

[8] Eikelboom, D.H., Andreadakis, A. and Andreasen, K., (1998) 'Survey of filamentous populations in nutrient removal plants in four European countries'. Water Science and Technology, 37(4-5), pp.281-289.

[9] Gray, N.F. (1989) Biology of Waste water Treatment. New York: Oxford University Press

[10] Gerardi, M. H. 2002. Settleability Problems and Loss of solids in Activated Sludge Process. Wiey-Interscience,

New York.

[11] Ghanizadeh, G. Sarrafpour, R. (2001) 'The effects of temperature and $\mathrm{pH}$ on settleability of activated sludge flocs'. Journal of Public Health, 30 pp. 139-142, Iran. [12] Hammer J.M., and Hammer, J.M.Jr (2008) Water and Waste Water Technology. $6^{\text {th }}$ edn. New Jersey-Ohio: Pearson Hall.

[13] Jeyanayagam, s. (n.d) Design and operations of final clarifiers [online] available from < http://www.fwrj.com/techarticle06/0106\%20tech2.pdf > [20 may 2016]

[14] Jenkins, d., Richard, M. G., and Daigger, G.T. (2003) Manual on the Causes and Control of Activated Sludge Bulking and Foaming and other Solids Separation Problems. $3^{\text {rd }}$ ed. London: IWA Publishing

[15] Jobbagy, A., Literathy B., and Tardy G. (2002) 'Implementation of glycogen accumulating bacteria in treating nutrient-deficient wastewater'. Journal of Water Science Technology, 46, pp. 185-190

[16] Jin, B., Wilen B.M., and Lant P. (2003) 'A Comprehensive insight into floc characteristics and their impact on compressibility and settleability of activated sludge'. Chemical Engineering Journal 95, pp.221-234.

[17] Koopman B., and Cadee K. (1983) 'Prediction of thickening capacity using diluted sludge volume index'. Journal of Water Research 17 (10), pp.1427-1431

[18] Kappeler, J., and Gujer W. (1994) 'Verification and applications of a mathematical model for aerobic bulking'.

Water Resource Journal, 28(2), pp.311-22

[19] Metcalf and Eddy (2003) 'Wastewater Engineering: Treatment and Reuse'. New York: McGraw-Hill.

[20] Mikkelsen, L.H., Gotfredsen, A.K., Agerbaek, M.L., Nielsen, P.H. and Keiding, K. (1996). 'Effects of colloidal stability on clarification and dewatering of activated sludge'. Water Science and Technology, 34(3-4), pp.449457.

[21] Metcalf and Eddy, Inc. (2004) Wastewater Engineering: Treatment and Reuse. $4^{\text {th }}$ edn. New York: McGraw-Hill.

[22] Ojo, P. and Ifelebuegu, A.O. (2015) 'optimizing final clarifier design and performance of activated sludge plant'.
International Journal of Environmental Engineering, 2(2374-1724) pp.33-41

[23] Pitman, A.R. (1984). 'Operation of Biological Nutrient Removal Plants, in Theory, Design and Operation of Nutrient Removal Activated Sludge Processes: edited by Wiechers H.N.S. Water Research Commission, Pretoria.

[24] Palm J.C, Jenkins D., and Parker D.S. (1980)

Relationship between organic loading, dissolved oxygen concentration and sludge settleability in the completely mixed activated sludge process. Journal of Water Pollution Control Federation, 52, pp.2484-506.

[25] Richard M. (1989) 'Activated sludge microbiology. The Water Pollution Control Federation, p. 350.

[26] Thompson, G., and Forster, C. (2003) 'Bulking in activated sludge plants treating paper mill wastewaters.' Water Research, 37(11), pp.2636-2644.

[27] Thompson, G., Swain, J., Kay, M. and Forster, C.F. (2001) 'The treatment of pulp and paper mill effluent: a review'. Bioresource Technology, 77(3), pp.275-286.

[28] Urbain, V., Block, J.C. and Manem, J. (1993) 'Bioflocculation in activated sludge: an analytic approach'. Water Research, 27(5), pp.829-838.

[29] Vesilind P.A (1968) 'Theoretical Considerations: Design Of Prototype Thickeners From Batch Settling Tests'. Journal of Water and Sewage Works pp.115, 302 [30] Wanner J. (1994) Activated sludge bulking and foaming control. Technomic Publishing co. inc. USA: Lancaster, pa.

Peter Ojo received his B.Eng. degree from Ahmadu Bello University Nigeria and his Master degree from Coventry University United Kingdom. He is currently a doctoral student (Ph.D.) in Coventry University. His research interests include water and wastewater treatment and process engineering. 